\title{
Curriculum Implementation: Strategies for Improved Learning Outcomes in Primary Schools in Kenya
}

\author{
Florence Kanorio Kisirkoi ${ }^{1} \&$ Godfrey $\mathrm{Mse}^{2,{ }^{*}}$ \\ ${ }^{1}$ Maasai Mara University, P.O Box 1246-20500, Narok, Kenya \\ ${ }^{2}$ Kenyatta University, P.O Box 43844-00100, Nairobi, Kenya \\ *Correspondence: Kenyatta University, P.O Box 43844-00100, Nairobi, Kenya. Tel: 254-722-327-745. E-mail: \\ godshedd@yahoo.com
}

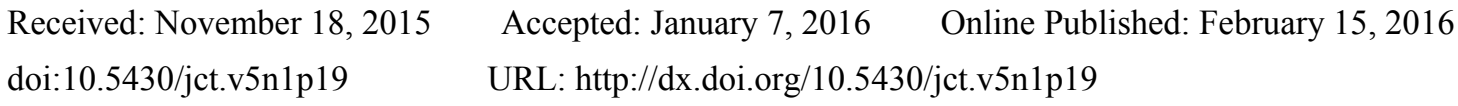

\begin{abstract}
Education in Kenya requires rethinking as the country faces the demands of educational and socio-economic transformation of the $21^{\text {st }}$ century. One of the general objectives of primary education in Kenya states that primary education should provide the learner opportunities to acquire literacy, numeracy, creativity and communication skills. There is evidence from research reports that the objective has not been fully met. A number of learners go through the primary school course without acquiring the basic literacy skills which negates the focus of the country to develop a knowledge based economy. The purpose of this study was to find out the extent to which teachers used teaching learning resources and learner centred strategies in primary school classrooms. The methodology adopted was survey research design. A total of 490 primary school teachers from five counties were purposively sampled and a total of 402 teachers participated; out of the total, 70 were observed teaching and 332 filled in a questionnaire. Out of 35 TAC tutors selected, 27 participated. A total of $80 \%$ of the teachers observed teaching used teacher centred teaching learning approaches with little learner involvement. The majority, $61.4 \%$ of those who filled in the questionnaire, indicated that they used teacher centred teaching learning approaches. Only 1(3.7\%) was 'good' in use of resources for teaching learning in class, the rest were poor or did not use resources. It was found that teaching and learning approaches employed in the classroom by most teachers was teacher centred and encouraged rote learning hence lacking in active student involvement in the learning process. It was recommended that there should be sustained school based teacher professional development activities specifically addressing pedagogy for improved curriculum implementation and ultimately improved learning outcomes.
\end{abstract}

Keywords: curriculum implementation, learning outcome, strategies, learner, teaching learning

\section{Introduction}

The study on which this paper is based investigated the extent to which teachers use learner centred teaching learning approaches and resources in public primary school classrooms in Kenya. The study was premised on the realization that education in Kenya requires rethinking as the country faces the demands of the socio-economic transformation of which centre around the need for a highly literate and skilled populace to drive the political, economic and social demands. One of the objectives of primary education in Kenya is 'Education should provide the learner opportunities to acquire literacy, numeracy, creativity and communication skills (Ministry of Education Science and Technology [MOEST], 2002). These are the basic critical skills in education that facilitate the learning of other concepts. There is evidence from research reports that the objective has not been fully met. Siringi (2012) reported that some candidates who sat KCPE could hardly construct a sentence in English or Kiswahili and displayed a composition written by a KCPE candidate that revealed a combination of unfavourable home factors, school factors, including poor teaching and mental conditions that should have been identified and addressed early through quality teaching. Another study by the Kenya National Examinations Council (KNEC,2010) on Monitoring class three Learner Achievements established that the mean score of literacy and numeracy was below the standardized mean of 300 . The study established that only about half of the pupils attained the desirable levels 3 and 4 of competency in literacy. In addition the Southern and Eastern Africa Monitoring Educational Quality (SACMEQ) assessment of literacy of Standard six pupils reported that while $64.8 \%$ of Standard six pupils had reached the minimum level of mastery on 
the reading test, only $23 \%$ had attained the English reading mastery level deemed desirable for successful learning in Standard seven (Bunyi, Wangia, Mukoma \& Limboro, 2011). Research has indicated that teaching and learning in Kenyan primary schools is characterized by rote transmission, teacher centred teaching learning approaches (Hardman et al, 2009 \& KNEC, 2010). Such approaches rarely allow internalization of learnt concepts because the more a child is provided opportunity to explore a concept, the more likely that the child will remember it (Dodge, Rudick \& Berke, 2015).

One of the theories guiding this study was constructivist theoretical framework by Bruner (1966). It posits that learning is an active process in which learners construct new ideas or concepts based upon their current and past knowledge and that the learner selects and transforms information, constructs hypotheses, and makes decisions, relying on a cognitive structure to do so. Cognitive structure (schema, mental models) provide meaning and organization to experiences and allows the individual to go beyond the information given. This is further strengthened by the view that constructing knowledge for oneself leads to genuine learning and mastery (Jones, 2007). Johnston (2004) explained that learning is not about passivity and order; it is about the messy process of discovery and construction of knowledge which leads to genuine learning and content mastery.

Scheerens (2008) further illustrated that constructivist teaching approaches produced the highest learning outcomes and summarized instructional variables in six categories and rated their learning effectiveness as indicated in Table 1. Constructivist teaching approach showed the highest teaching effect on learning outcome with mean of 135 followed by supportive classroom climate created by the teacher with mean of 117 ; teacher classroom management with mean of 095; structured, direct, transmission with mean of 087; curricula with mean of 077 and feedback, monitoring and assessment with mean of 065 ; in that order. Therefore special stress should be laid on the use of constructivist approach and establishing a quality learning environment in the classrooms. All the other variables should also be addressed because they all contribute to learning.

Table 1. Teaching Factors

\begin{tabular}{lll}
\hline No. & Category of Teaching Factor & Mean Effect on Learning \\
\hline i) & Curricular & .077 \\
ii) & Teacher classroom Management & .095 \\
iii) & Teaching Strategy (structured, direct, transmission) & .087 \\
iv) & Teaching Strategy (constructivist-oriented) & .135 \\
v) & Climate/environment, support, positive interactions & .117 \\
v) & Feedback/monitoring/ assessment/ tests & .065 \\
\hline
\end{tabular}

\section{Source: Scheerens (2008)}

A study by the Organization for International Co-operation and Development (OECD, 2009) indicated that there are twelve principles of effective teaching. The principles were identified as creating supportive classroom climate, providing learners opportunity to learn, raising teacher and learner enthusiasm, enhancing learner creativity and innovativeness, establishing learning orientation, promoting coherent content presentation. The other principles of effective teaching include providing learners' opportunity for thoughtful discourse, practice and application; providing student assistance-scaffolding, cooperative learning and goal oriented assessment in measuring expected learning outcomes. Others reported learning variables include teacher enthusiasm or business like behaviour, providing student opportunity to learn criterion material, making use of stimulating comments, varying level of cognitive questions and class interactions 8

Brain research has also supported the need for relaxed learner friendly environment. It has shown that learning takes place in the neo cotex which does not function well under stress or fear (Bandura, 1997). Therefore the learning environment should be attractive, friendly and stress free. Constructivists emphasize that teachers should act as facilitators who provide appropriate activities and support pupils to personally construct their own meanings rather than receive them ready made from the teacher (Scheerens, 2008).

\section{Methodology, Findings and Discussions}

The study employed descriptive survey research design and observed ethical considerations throughout. Three questionnaires and an observation schedule were used to gather data. It was conducted in five counties in Kenya. Cluster sampling technique was employed in different stages in a multistage sampling. A total of 490 primary school teachers from the five counties were purposively sampled, from which a total of 402 teachers participated in the 
study. Out of that total, 70 were observed teaching and 332 filled in a questionnaire. Out of 35 TAC tutors selected, 27 participated. The five counties were selected using purposive sampling, then 12 sub counties were sampled using simple random sampling from the five counties, then 35 zones found in the sampled sub counties were all used in the study and from the 35 zones all the 35 TAC tutors serving were used in the study. From the 35 zones two schools were selected per zone using purposive sampling in order to select only the schools with teachers who had attended Teacher Advisory Centres (TACs) teacher professional development activities. Three questionnaires and one observation schedule were used to collect data. Content validity of the instrument was determined using objectives of the study as the criteria. Split half reliability was used to verify the degree to which the instruments yielded consistently the same results after the repeated trials using Spearman rho coefficient of correlation or rank order following the formula:

rho $=\underline{1-6 \sum \mathrm{d}}$ to establish reliability of half test.

$$
\mathrm{n}\left(\mathrm{n}^{2}-1\right)
$$

Reliability coefficient was then established for total test using Spearman Brown Prophesy formula:

rtotal test $=\underline{2(\mathrm{r} \text { split half })}$

$1+(\mathrm{r}$ split half).

The four research instruments used in the study yielded $.75, .75, .77$ and .85 correlation coefficient hence acceptable for use in the study. According to Plowright (2011), a correlation coefficient of at least .5 is acceptable while Kerlinger (2000) put it that 7 correlation coefficient and above was acceptable. Descriptive Statistics, specifically frequencies and percentages, were employed to analyze data. The findings were presented on the following themes: learner centred teaching learning approaches; classroom interactions, Learner Enthusiasm in the Learning Environment; Teachers' Behaviour During Lesson Presentation and Teachers' Use of Teaching and Learning Resources.

\section{Learner Centred Teaching Learning Approaches.}

The study sought to find out the extent to which teachers used learner centred teaching learning approaches for instruction. Classroom Observation Schedule and the questionnaire for teachers and the other by TAC tutors were used to gather data. The type of classroom interactions, learner enthusiasm, teachers' behaviour in class, teachers' and dominant teaching approaches as indicators of learner centred classroom teaching according to Sheerens (2008) were investigated as variables in Learner centred teaching learning approaches .

\section{Classroom Interactions}

The researchers observed the type of interactions dominating the class as they observed teachers teach using the classroom observation schedule. Table 2 presents the findings of the observation. The majority $55(80 \%)$ of the teachers observed by the researchers were using teacher-dominant interaction in class frequently; interactions that were largely initiated by the teacher. This is a characteristic of teacher centred teaching approach. On the other hand, in $61.9 \%$ observations no learner initiated interactions were observed. Learner -learner interaction, another characteristic of learner centred approach was also not used in teaching in $56 \%$ observations. These findings demonstrate that teacher-centred approaches are dominantly applied by teachers when in class. The class sessions were characterized by dominant teacher talk, questioning and chorus answers which allowed no further discussions. The teacher determined the correctness of responses with no explanation and room for discussion. The teacher also determined who was to answer questions in class. The focus appeared to be transmitting content in a manner that learners would reproduce easily through rote learning. There was little active learning, construction of meaning, discovery and collaborative learning. 
Table 2. Classroom Interactions

\begin{tabular}{|c|c|c|c|c|c|c|}
\hline \multirow[b]{2}{*}{ Rating } & \multicolumn{2}{|c|}{$\begin{array}{l}\text { Teacher-learner } \\
\text { interaction }\end{array}$} & \multicolumn{2}{|c|}{$\begin{array}{l}\text { Learner-teacher } \\
\text { Interaction }\end{array}$} & \multicolumn{2}{|c|}{$\begin{array}{c}\text { Learner-learner } \\
\text { Interaction }\end{array}$} \\
\hline & f & $\%$ & f & $\%$ & $\mathbf{F}$ & $\%$ \\
\hline Frequently & 55 & 80 & 7 & 12.4 & 7 & 14 \\
\hline Average & 8 & 10.7 & 18 & 25.7 & 21 & 30 \\
\hline None & 7 & 9.3 & 45 & 61.9 & 42 & 56 \\
\hline Total & 70 & 100 & 70 & 100.0 & 70 & 100 \\
\hline
\end{tabular}

Harvel (2003) argued that interactivity is critical in the development of critical thinking. The teacher, instructor should be able to create a learning environment that motivates students to take responsibility for their own learning and construct their own meaning by use of resources for learning failure to which learning would be rote transmission which curtails creativity.

\section{Learner Enthusiasm in the Learning Environment}

The researchers, using the classroom observation schedule, observed learner enthusiasm in classrooms during instruction. It is a variable dominant in learner centred learning environments (Scheerens, 2008) but was investigated in isolation because it is a key variable in effective teaching and learning. The researchers' findings were compared with those of the Teacher Advisory Centre (TAC) tutors. Table 3presents the findings.

Table 3. Learner Enthusiasm

\begin{tabular}{lcccc}
\hline & TAC tutors & \multicolumn{3}{c}{ Researcher } \\
\hline Rating & $\mathbf{f}$ & $\mathbf{\%}$ & $\mathbf{f}$ & $\%$ \\
High & 11 & 42.7 & 10 & 14.3 \\
Average & 11 & 42.7 & 40 & 57.1 \\
Low & 5 & 14.9 & 20 & 28.6 \\
\hline Total & $\mathbf{2 7}$ & $\mathbf{1 0 0 . 0}$ & $\mathbf{7 0}$ & $\mathbf{1 0 0}$ \\
\hline \multicolumn{1}{c}{$(\mathbf{N}=\mathbf{2 7})$} & & $\mathbf{( N = 7 0 )}$ & &
\end{tabular}

The majority $40(57.1 \%)$ of the classes were rated by researcher as average in learner enthusiasm. The TAC tutors rated learner enthusiasm between high and average; with $42.7 \%$ rated high and average respectively. Therefore learner enthusiasm tends to have been average which was just fair.

Many learners were not found to be enthusiastic in class. It was only a few who responded to the teachers' questions in teacher centred classroom environment where the teachers dominated the class and failed to induce learner enthusiasm. Many of the learners remained dull perhaps because of teacher centred teaching method and teacher learner type of interaction which did not give them a chance to participate in class. In most cases the teachers appointed pupils who were to answer questions and their responses were either right or wrong. Many teachers therefore did not provide many students opportunity to participate in discussions or explanation.

\section{Teachers' Behaviour during Lesson Presentation}

Teachers' behaviour during lesson presentation was reported as observed by the researcher and the TAC tutor and was critical in determining the level of friendliness and freedom in the learning environment. Questionnaire for TAC tutors and classroom observation schedule were used to collect data. Table 4 indicates that the majority $61(89.3 \%)$ of the teachers observed by the researcher teaching and $26(96.3 \%)$ observed by the TAC tutors in course of their classroom observation were found to be exciting, lively and friendly to the learners. Both the researcher and the TAC tutors tended to agree in their observations and both found teachers very enthusiastic when teaching in class which was unlike the learners who were rather dull as presented in Table 3. The teachers were enthusiastic as they talked 
most of the time in a chalk and talk classroom environment. The teacher centred approach to teaching and the teacher learner type of interactions did not give learners a chance to participate in class. The teachers failed to induce learner enthusiasm. Teacher enthusiasm in learner friendly environment would have raised learner enthusiasm but it did not which was in contrast to Feldman (2007) who argued that teacher enthusiasm has power to influence students' cognitive, affective and motivational outcomes with its intrinsic motivation, where the learner is engaged but in this case the learner was a kind of spectator of teachers' endless talk in self amusement that never ignited the class.

Table 4. Teachers' Behaviour in Class

\begin{tabular}{|c|c|c|c|c|}
\hline \multirow[t]{2}{*}{ Teachers' manner } & \multicolumn{2}{|c|}{ Researcher } & \multicolumn{2}{|c|}{ TAC tutors } \\
\hline & f & $\%$ & f & $\%$ \\
\hline Friendly, lively and exciting & 61 & 89.3 & 26 & 96.3 \\
\hline Boring, & 3 & 3.7 & 0 & 0 \\
\hline Unfriendly & 6 & 15. & 1 & 3.7 \\
\hline Total & 70 & 100.0 & 27 & 100.0 \\
\hline
\end{tabular}

All the learners were engaged only when writing exercises as the teacher went round marking one question for most of the students and then the bell would end the class. Hardman et al (2009) had found the same transmission type of teaching learning approach.

Research has found that learner centred teaching learning approaches lead to improved learning outcomes in a number of cases. A study by the Organization for International Co-operation and Development (OECD, 2009 \& Brophy 2001) indicated that there are twelve principles of effective teaching which support learner centred teaching learning approaches with use of teaching learning resources as opposed to teacher centred teaching learning approaches. The principles were identified as creating supportive classroom climate, providing learners opportunity to learn, raising teacher and learner enthusiasm, enhancing learner creativity and innovativeness, establishing learning orientation and promoting coherent content presentation. The other principles of effective teaching include providing learners' opportunity for thoughtful discourse, practice and application; providing student assistance-scaffolding, cooperative learning and goal oriented assessment in measuring achievement of the expected learning outcomes. These are aspects of learner centred teaching learning approaches. Reported effective teaching learning characteristics include teacher enthusiasm or business like teacher behaviour, providing student opportunity to learn criterion material, making use of stimulating comments, varying levels of cognitive questions and classroom interactions (European Union, 2010). Research has therefore indicated need for learner engagement in learning.

An example of positive impact of learner centred approach is Secondary school science and mathematics experience in secondary schools in Kenya as practised by the Strengthening Mathematics and Science in Secondary Education (SMASSE) initiative which applied the principle of Activity Student Experiment Improvisation (ASEI) to upgrade aspects of teaching and demonstrated positive impact of use of learner entred teaching learning approach. It changed teaching mode from teacher centred teaching to student centred learning; from theoretical method to experiment; from chalk and talk to research based approach. It also changed approaches from teacher demonstrations to small scale learner improvisation through Plan Do See (lesson study) and Improve (PDSI) approaches which were interactive and learner centred. The SMASSE impact study reported that the impact observed on students was that students were actively involved in learning (MOEST, 2009). They showed great learning interest and responsiveness, attended lessons more punctually, carried out discussions beyond class time and asked questions in and out of class. The approach was reported to have demystified mathematics activities having been related to students 'real life' experiences. The reported outcome supports the report by Scheerens (2008) and Jones (2007) that constructivist teaching approach has high learning outcome and is the preferred approach for teaching. The experience could be tried by all teachers in all schools regardless of the level. It is observed that constructivist approach and use of resources are inseparable aspects of learner centred teaching learning approaches.

\section{Teachers' Use of Teaching and Learning Resources}

TAC tutors were required to report on observed teachers' use of resources as teaching aids to enhance teaching and learning besides the course book. Data was gathered using TAC Effectiveness Questionnaire for TAC Tutors. 
From the data in Table 5. Only 1(3.7\%) of the TAC tutors reported that resources were used to aid teaching and learning. The majority $15(56 \%)$ of TAC tutors reported that no other resources were used by teachers in class except textbooks; $2(7.4 \%)$ TAC tutors reported that resources were presented in class but were not used.

Table 5. Teachers' Use of Resources

\begin{tabular}{|c|c|c|}
\hline Use of Resources & f & $\%$ \\
\hline Used for teaching and learning & 1 & 3.7 \\
\hline Presented in class but not used & 2 & 7.4 \\
\hline No other resources used except textbook & 15 & 55.6 \\
\hline Poor use - reading textbook content in class & 9 & 33.3 \\
\hline Total & 27 & 100.0 \\
\hline
\end{tabular}

Teachers were required to report on frequency of their use of teaching learning resources to aid classroom instruction. TAC effective Questionnaire for Teachers was used to collect data. Table 6 indicates that $50 \%$ of the teachers reported that they rarely used resources to aid instruction while $28 \%$ of them had 'never' used resources to enhance classroom instruction. This concurs with the report by teachers and TAC tutors that teachers did not use resources to enhance classroom instruction as required.

Table 6. Teachers' Frequency of Use of Resources

\begin{tabular}{lcc}
\hline Use of Resources & f & $\mathbf{\%}$ \\
\hline Always & - & - \\
Frequently & 79 & 22 \\
Rarely & 164 & 50 \\
Never & 89 & 28 \\
\hline Total $\quad(\mathrm{N}=332)$ & $\mathbf{3 3 2}$ & $\mathbf{1 0 0 . 0}$ \\
\hline \multicolumn{1}{c}{$\quad$} &
\end{tabular}

From the findings, it was evident that the extent to which teachers use teaching learning resources to enhance instruction was minimal.

Resources aid in addressing more than one sense and the more senses addressed the better the learning outcome (Doyle \& Robson, 2002). Resources support students learning and have been found to significantly increase students' achievement (Bitner, N. \& Bitner, 2002). They also cater for learners' individual differences and address different learning styles. Research has also shown that learners learn best concepts when they are taught by use of concrete resources because resources help to make abstract content concrete (Schwille, Dembere \& Schubert, 2007). Resources promote perception and enhance understanding. They help to reinforce the spoken word, aid memory, retention through involvement of many senses; repetition through a different medium, motivate and arouse learners' interest though interactions (Maduna, 2002). While only about $12 \%$ of what we learn comes from hearing, $75 \%$ comes from what we see (Doyle \& Robson, 2002).

Educators have recognized the power of audio-visual materials to capture the attention of learners; they increase learners' motivation and enhance their learning experience. Mayer (2001) reported that among teachers who report using TV or video for two or more hours per week, two-thirds find that students learn more when TV or video is used, and close to $70 \%$ found that student motivation increases with use of teaching learning resources. More than half of frequent users of resources also found that students use new vocabulary as a result of use of video (Mayer, 2001). Use of modern technology as learning resources increases learning effects (Ivet \& Baron, 2002). Failure to use resources in learning negatively impacts on quality of teaching and learning outcomes. Use of resource is so critical that the modern trend is shifting to integrate technology in instruction to be able to enhance use of resource from technology to make learning more learner centred and to develop learner creativity, innovativeness and facilitate them to construct their own knowledge; technology enhanced resources promote learner creativity and knowledge construction (Koehler, 2011). 
Maduna (2002) reported that researchers have found out that teaching aids enable the teacher and children to engage in solid conversations on concrete and abstract concepts. Maduna also put forward an argument that use of concrete objects for learners' manipulation, enable teachers to demonstrate and illustrate mathematical concepts, properties and procedures to create an environment conducive to learning.

Resources enable the teacher to organize learning in an authentic setting because learners do not only need abstract concepts; they also need to use the conceptual tools in an authentic activity in real world relevance and utility. They could be made by the teacher in many ways including using computer; they could also be modelled. They could also be collected from the environment, downloaded from the internet and customised for use in class and sourced from Teacher Education in Sub Saharan Africa (TESSA) from the internet. The teacher would need to be creative, innovative and resourceful to access and use the resources in teaching learning process in order to enable learners to construct their own knowledge which requires provision of rich open authentic learning environment to challenge learners to cope with complex environment and to take more responsibility for their own learning. Therefore from the given reports, use of teaching learning resources for instruction increases learning outcome and lack of its use as established in this study impacts negatively on learning.

Nevertheless a significant number of teachers in this study did not use resources when teaching

\section{Conclusions}

The study established that the extent to which teachers use learner centred teaching learning approaches and resources in teaching in class was inadequate. Learner centred teaching learning approaches that involve learners in learning were hardly used by the teachers in this study. The commonly used teaching learning approaches by teachers was teacher centred and mainly the lecture and question and answer approaches and rote learning. Teacher learner interaction was the dominant mode of class interaction observed by the TAC tutors and the researchers where the teacher was the initiator of any question which the learner answered and even then not all learners were involved. Resources were hardly used in class.

\section{Recommendations}

The teacher should be prepared for future trends where teaching and learning will be influenced by constructivists; focus will be on competencies and innovativeness and more technology enabled teaching learning strategies. Teachers need to be trained and supported to understand the learning gains and learning outcomes resulting from learner centred teaching approaches and use of teaching learning resources as opposed to teacher centred teaching approaches. They will also need to be trained in development, access and use of teaching learning resources. The teachers will also need to be supported in implementation of the skills in classroom instruction. There should be a sustained teacher professional development programme.

\section{References}

Bandura, A. (1997). Self Efficacy. The Exercise of Self Control. New York. Freeman..

Bitner, N., \& Bitner, J. (2002). Integrating Technology into the Classroom: Eight Keys to Success. Journal of Technology and Teacher Education, 10(1), 95-100.

Brophy, J. (2001). Generic Aspects of Effective Teaching. Tomorrow Teachers. New York. McCuthan Publishing Company.

Brunner, J. (1966). Towards a Theory of Instruction. Cambridge: Belkapp Press.

Bunyi, G., Wangia, J., Mukoma C., \& Limboro, C. (2011). Learning to Teach Mathematics and Influence on Practice. A Study of Teacher Education in Kenya. William and Flora Hewlett Foundation.

Doyle, C., \& Robson, K. (2002). Accessible curricula: good practice for all. UWI Press: Cardiff Last Modified: 4 June, 2010.

Dodge, D. D., Colker, J. L., \& Heroman, C. (2015). Creative Curriculum for Pre school (4 ${ }^{\text {th }}$ Ed.). Washington DC Cataloging in Publication.

European Union. (2010). Teacher Professional Development. Europe International Comparison. An Analysis of teacher professional development based on OECDs Teaching and Learning International Survey (TALIS). A Secondary analysis based on the TALIS dataset. Luxenburg. University of Twente. 
Feldman, K. A. (2007). Identifying Exemplary Teachers and Teaching: Evidence from Student Ratings. The scholarship of teaching and learning in higher education - An evidence-based perspective (pp. 93-143). Dordrecht: Springer.

Hardman, F., Abdi-Kadir, J., Agg, C., Migwi, J., Ndambuki, J., \& Smith, F. (2009). Changing Pedagogical Practice in Kenyan Primary Schools: the impact of school based training. Comparative Education, 45, 65-86. http://dx.doi.org/10.1080/03050060802661402

Harvell, S. (2003). Professional Development. Teacher Professional Development: It's Not an Event, It's a Process. Texas: CORD.

Ivet, M., \& Baron, R. (2002). Multi Media projects in Education: Designing, Producing and Assessing. Connecticut: Westport G Libraries.

Johnston, P. (2004). Choice words: How our language affects children's learning. Portland, ME: Stenhouse Publishers.

Jones, L. (2007). The student-centered Classroom. New York: Cambridge University Press Alexandria Virginia.

Kerlinger, F. (2000). Foundations of Behavioural Research. Harcourt College Publishers.

KNEC. (2010). Monitoring learner Achievement Study for Class Three in Literacy and Numeracy. (NASMLA) Class 3 Study. Nairobi. KNEC.

Koehler, M. (2011). Pedagogical Content Knowledge Posted in Core. Retrieved $13^{\text {th }}$ May 2011 from http://mkoehler.educ.msu.edu/tpack/category/core/

Maduna, J. (2002). An Analysis of the use of teaching Aids and the implication for teaching Mathematics in Iqwaqwa phase one schools in South Africa. A Master of Arts Thesis. Montreal. Concordia University.

Mayer, R. (2001). Multimedia learning. London: Cambridge University Press. http://dx.doi.org/10.1038/35085529

MOEST. (2002). Primary Education Syllabus. Nairobi: KIE.

MOEST (2009). Strengthening Mathematics and Science in Secondary Education. A Hand book. Nairobi: SMASSE Centre.

OECD. (2009). Teaching and Learning International Survey.(TALIS). Creating Effective Teaching and Learning Environments. Paris: OECD.

Plowright, D. (2011). Using Mixed Methods Frameworks for an Integrated Methodology. London: SAGE.

Scheerens, J. (2008). System Level Indicators Paper for INES Network c. Enschede: University of Twente Educational Technology, 25(1), 101-116.

Schwille, J., Dembele, M., \& Schubert, J. (2007). Global Perspectives on Teacher Learnings: Improving Policy and Practice. Paris: UNESCO.

Siringi, S. (2012, October Monday 1 $\left.{ }^{\text {st }}\right)$. KNEC: Many Pupils can’t Write. The Daily Nation p.9. 